\title{
IDENTIFIKASI KEMAMPUAN GURU DALAM MELAKUKAN PENILAIAN HASIL BELAJAR BERBASIS KURIKULUM 2013 DI MIN PUNIA MATARAM
}

\author{
Mulabbiyah \\ Universitas Islam Negeri (UIN) Mataram \\ Jl. Pendidikan No. 35 Mataram \\ Email:mulabbiyah@uinmataram.ac.id
}

\begin{abstract}
Abstrak: Penelitian ini merupakan penelitian deskriptif kuantitatif yang bertujuan untuk mengidentifikasi kemampuan guru MIN Punia Mataram dalam melaksanakan penilaian hasil belajar berbasis kurikulum 2013 yang mencakup kemampuan merencanakan penilaian, melaksanakan penilaian, melakukan pengolahan hasil penilaian dan menindaklanjuti hasil penilaian. Populasi penelitian berjumlah 20 orang guru dengan sampel penelitian berjumlah 13 orang guru yang dipilih secara purposive sampling. Adapun variabel dalam penelitian ini berupa kemampuan guru dalam melaksanakan penilaian hasil belajar. Data kemampuan guru diperoleh melalui instrumen berbentuk angket tertutup dan semiterbuka. Data dianalisis menggunakan analisis statistik deskriptif berupa persentase, hasilnya menunjukkan bahwa kemampuan guru MIN Punia Mataram dalam merencanakan penilaian tergolong sangat baik (90\%), kemampuan melaksanakan penilaian tergolong baik $(73,33 \%)$, kemampuan mengolah hasil penilaian tergolong sangat baik $(93,33 \%)$ serta kemampuan memanfaatkan dan menindaklanjuti hasil penilaian tergolong baik (53,33\%). Berdasarkan hasil ini disimpulkan bahwa kemampuan guru MIN Punia Mataram dalam melaksanakan penilaian hasil belajar berdasarkan kurikulum 2013 sudah baik.
\end{abstract}

\begin{abstract}
This research is quantitative descriptive research which aims to identify the ability of MIN Punia Mataram teacher in conducting the learning outcomes assessment based on curriculum 2013 which includes the ability to plan the assessment, to carry out the assessment, to perform the processing of assessment result and to follow up the assessment result. The population of this research is 20 teachers with the research sample is 13 teachers selected by purposive sampling. The variable of the study is the of teachers' ability in implementing assessment of learning outcomes. The data of teachers' ability is obtained through closed and semiterbased questionnaire instruments. The data were analyzed by using descriptive statistical analysis in the form of percentage. The result showed that the ability of MIN Punia Mataram teachers to plan the assessment was very good (90\%); the ability to carry out the assessment was good $(73.33 \%)$; the ability to process the assessment result was very good (93,33\%); and the ability to utilize and to follow up the assessment result is quite good (53.33\%). Based on these results, it is concluded that the ability of MIN Punia Mataram teachers in implementing the assessment of learning outcomes based on the 2013 curriculum is good.
\end{abstract}

Kata kunci: penilaian hasil belajar, kurikulum 2013, kemampuan guru

\section{PENDAHULUAN}

Guru sebagai pendidik profesional, dituntut untuk memiliki empat kompetensi, yaitu kompetensi pedagogik, kompetensi kepribadian, kompetensi sosial dan kompetensi 
profesional $^{1}$. Kompetensi pedagogik sebagai salah satu kompetensi yang harus dikuasai guru telah dijabarkan pada lampiran peraturan menteri pendidikan nasional nomor 16 tahun 2007 diantaranya mampu menyelenggarakan penilaian dan evaluasi proses dan hasil belajar serta mampu memanfaatkan hasil penilaian dan evaluasi².

Mengacu kepada peraturan tersebut, seharusnya semua guru memiliki kemampuan untuk melaksanakan penilaian hasil belajar dan memanfaatkan hasilnya untuk tindak lanjut berdasarkan kurikulum yang berlaku. Secara bertahap, mulai tahun ajaran 2013/2014 Pemerintah melalui Kementerian Pendidikan dan Kebudayaan menerapkan kurikulum yang disebut dengan kurikulum $2013^{3}$ yang merupakan penyempurnaan dari kurikulum tingkat satuan pendidikan (KTSP). Selanjutnya, Kementerian Agama sebagai kementerian yang menaungi pendidikan madrasah menindaklanjuti Permendikbud di atas dengan mengeluarkan KMA nomor 117 tahun 2015 yang menginstruksikan penerapan kurikulum 2013 di madrasah mulai tahun ajaran 2014/2015.

Berdasarkan Surat Keputusan Direktur Jenderal Pendidikan Madrasah nomor 481 tahun 2015 tentang penetapan madrasah pendampingan implementasi kurikulum 2013, sebutkan bahwa MIN Punia Mataram merupakan salah satu madrasah yang mengimplementasikan kurikulum 2013. Disebutkan juga bahwa guru di madrasah kurikulum 2013 akan mendapatkan pelatihan dan pendampingan secara merata. ${ }^{5}$

MIN Punia Mataram sudah mengimplementasikan kurikulum 2013 secara bertahap mulai dari tahun ajaran 2014/2015, dimulai dari kelas I dan kelas IV, dilanjutkan kelas II dan IV pada tahun 2015/2016, serta kelas III dan VI pada tahun 2016/2017, sehingga pada saat ini semua kelas sudah mengimplementasikan kurikulum 2013 ${ }^{6}$. Semua guru MIN Punia Mataram juga sudah mengikuti rangkaian pelatihan kurikulum 2013, baik yang diselenggarakan oleh Kementerian Agama maupun Kementerian Pendidikan dan Kebudayaan.

Berkaitan dengan itu, penting untuk diidentifikasi bagaimana kemampuan guru khususnya di MIN Punia Mataram dalam melakukan penilaian hasil belajar yang merupakan bagian dari implementasi kurikulum 2013 sebagai bentuk evaluasi.

\section{METODE PENELITIAN}

Penelitian ini merupakan penelitian deskriptif kuantitatif ${ }^{7}$. Variabel penelitian berupa kemampuan guru dalam melaksanakan penilaian hasil belajar. Populasi penelitian berjumlah 20 orang guru dengan sampel penelitian berjumlah13orang guru dan 65 siswa yang dipilih secara purposive sampling.

\footnotetext{
${ }^{1}$ Peraturan Pemerintah Republik Indonesia nomor 74 tahun 2008 pasal 13.

${ }^{2}$ Lampiran Peraturan Menteri Pendidikan Nasional nomor 16 Tahun 2007, h. 9-11.

${ }^{3}$ Permendikbud nomor 81 A tahun 2013 pasal 1.

${ }^{4}$ KMA nomor 117 tahun 2014.

${ }^{5}$ Surat Keputusan Direktur Jenderal Pendidikan Madrasah nomor 481 tahun 2015 tentang penetapan madrasah pendampingan implementasi kurikulum 2013

${ }^{6}$ Hasil wawancara dengan H. Marzuki, S.Pd, Kepala MIN Punia, tanggal 4 April 2017.

${ }^{7}$ Sugiyono, Metode Penelitian Pendidikan;Pendekatan Kuantitatif, Kualitatif, dan R\&B, (Bandung: Alfabeta, 2010), h. 7.
} 
Datakemampuan guru diperoleh melalui instrumen berbentuk angket. Ada dua instrumen yang digunakan yaitu instrumen guru dan instrumen untuk siswa. Instrumen untuk guru dalam bentuk angket tertutup dan semi terbuka, yang terdiri dari17 pertanyaan dengan perincian dua pertanyaan untuk mengukur kemampuan guru merencanakan penilaian, 11 pertanyaan untuk mengukur kemampuan guru melaksanakan penilaian, dua pertanyaan untuk mengukur kemampuan guru mengolah hasil penilaian dan dua pertanyaan untuk mengukur kemampuan guru memanfaatkan dan menindaklanjuti hasil penilaian. Sedangkan instrumen untuk siswa dalam bentuk angket tertutup, yang terdiri dari 43 pertanyaan, yang terdiri dari 6 pertanyaaan tentang pelaksanaan penilaian sikap, 35 pertanyaan tentang pelaksanaan penilaian pengetahuan, dan 2 pertanyaaan tentang pelaksanaan penilaian keterampilan. Selanjutnya data yang diperoleh dianalisis menggunakan analisis statistik deskriptif berupa persentase.

\section{HASIL DAN PEMBAHASAN}

Penelitian ini bertujuan untuk mengidentifikasi kemampuan guru MIN Punia Mataram dalam melaksanakan penilaian hasil belajar berbasis kurikulum 2013 yang mencakup kemampuan merencanakan penilaian, melaksanakan penilaian, melakukan pengolahan hasil penilaian dan menindaklanjuti hasil penilaian. Data tingkat kemampuan guru MIN Punia Mataram dalam melaksanakan penilaian hasil belajar berdasarkan kurikulum 2013 yang diperoleh melalui angket dikatagorikan kedalam 4 tingkat yaitu : Sangat Baik, Baik, Kurang dan Sangat Kurang.

Kemampuan guru MIN Punia Mataram dalam merencanakan penilaian secara umum tergolong sangat baik.Hal ini diketahui berdasarkan hasil analisis data yang menunjukkan bahwa sebanyak 76,67\% guru memiliki kemampuan pada kategori sangat baik,13,33\% pada kategori baik, $10 \%$ pada kategori kurang dan 0,00\% sangat kurang (seperti tertera pada Tabel 1). Ini menunjukkan bahwa kemampuan guru MIN Punia Mataram dalam melakukan perencanaan penilaian sudah sangat baik, di mana $90 \%$ guru masuk dalam kategori sangat baik dan baik.

Tabel 1. Kemampuan Guru Merencanakan Penilaian

\begin{tabular}{|c|c|c|c|}
\hline \multirow{2}{*}{$\begin{array}{c}\text { Tingkat } \\
\text { Kemampuan Guru }\end{array}$} & Sikap & Pengetahuan \& Keterampilan & Rata-rata \\
\cline { 2 - 4 } Sangat Baik & $80 \%$ & $73,34 \%$ & $76,67 \%$ \\
\hline Baik & $13,33 \%$ & $13,33 \%$ & $13,33 \%$ \\
\hline Kurang & $6,67 \%$ & $13,33 \%$ & $10 \%$ \\
\hline Sangat Kurang & $0 \%$ & $0 \%$ & $0 \%$ \\
\hline
\end{tabular}

Jika dilihat berdasarkan tiap aspek yaitu perencanaan penilaian sikap, dan perencanaan penilaian pengetahuan serta keterampilan, maka dapat terlihat bahwa guru MIN Punia Mataram memiliki kemampuan lebih baik dalam melakukan perencanaan penilaian sikap dari pada perencanaan penilaian pengetahuan dan keterampilan. Ini 
terlihat dari besarnya persentase guru yang memiliki kemampuan pada kategori sangat baik dan baik, yaitu pada perencanaan penilaian sikap persentase guru yang memiliki kemampuan dengan kategori sangat baik sebesar $80 \%$ dan kategori baik sebesar 13, 33 $\%$, jadi jumlah persentase keduanya sebesar 93,33 \%, sedangkan pada perencanaan penilaian pengetahuan dan keterampilan persentase guru yang memiliki kemampuan dengan kategori sangat baik sebesar 73,34 \% dan kategori baik sebesar 13, $33 \%$, jadi jumlah persentase keduanya sebesar $86,67 \%$.

Dengan demikian dapat dikatakan kemampuan guru-guru MIN Punia Mataram dalam melakukan perencanaan sikap secara umum sudah sangat baik,namun meskipun demikian masih ada guru yang memiliki kemampuan kategori kurang yaitu sebesar 6,67 $\%$. Guru yang masuk dalam kategori memiliki kemampuan kurang, karena keengganan dalam melengkapi dokumen-dokumen yang menunjang penilaian yang dilakukan, seperti guru tidak menyiapkan lembar penilaian antar teman sebaya.

Begitu juga pada aspek pengetahuan dan keterampilan guru MIN Punia Mataram secara umum sudah memiliki kemampaun yang sangat baik, meskipun masih ada sebesar 13,33 \% yang masuk dalam kategori kurang. Guru yang masuk dalam kategori kurang disebabkan dalam melakukan perencanaan penilaian pengetahuan dan keterampilan tidak menyiapkan kisi-kisis soal tes tertulis dan tes lisan untuk penilaian harian, kebanyakan hanya menyiapkan kisi-kisi untuk soal tes ulangan tengah semester dan semester.

Adapun kemampuan guru MIN Punia Mataram dalam pelaksanaan penilaian dapat digolongkan sudah baik. Hal ini diketahui dari hasil analisis secara keseluruhan aspek pelaksanaan penilaian diperoleh sebesar 33,33 \% yang memiliki kemampuan pada kategori sangat baik, $40 \%$ pada kategori baik dan 26,67\% yang masih pada kategori kurang serta $0 \%$ pada kategori sangat kurang (seperti terlihat pada tabel 2). Artinya, sudah 73,33\% masuk dalam kategori sangat baik dan baik. Dengan demikian, dapat dikatakan bahwa kemampuan guru MIN Punia Mataram dalam merencanakan penilaian lebih baik dibandingkan dengan kemampuan mereka dalam melaksanakan penilaian. Hal ini dapat terjadi karena perencanaan penilaian yang disusun oleh guru MIN Punia Mataram tidak sepenuhnya dapat terealiasi dalam pelaksanaannya. Oleh karena itu, guru MIN Punia Mataram perlu meningkatkan kemampuannya dalam mensinergikan dan merealisasikan apa yang telah direncanakan agar dapat terlaksana secara maksimal pada pelaksanaan penilaian.

Tabel 2. Kemampuan Guru Melaksanakan Penilaian

\begin{tabular}{|c|c|c|c|c|}
\hline \multirow{2}{*}{$\begin{array}{c}\text { Tingkat } \\
\text { Kemampuan Guru }\end{array}$} & Sikap & Pengetahuan & Keterampilan & Rata-rata \\
\cline { 2 - 5 } & $6,67 \%$ & $93,33 \%$ & $0,00 \%$ & $33,33 \%$ \\
\hline Sangat Baik & $8,6,66 \%$ & $6,67 \%$ & $26,67 \%$ & $40,00 \%$ \\
\hline Baik & $6,67 \%$ & $0,00 \%$ & $73,33 \%$ & $26,67 \%$ \\
\hline Kurang & $0,00 \%$ & $0,00 \%$ & $0,00 \%$ \\
\hline Sangat Kurang & $0,00 \%$ & $0,000 \%$ & \multicolumn{4}{c}{}
\end{tabular}


Sementara itu kemampuan guru MIN Punia Mataram dalam melaksanakan penilaian jika dilihat berdasarkan tiap aspek yaitu aspek pelaksanaan penilaian sikap, pelaksanaan penilaian pengetahuan dan pelaksanaan penilaian keterampilan, maka berdasarkan analisis data diketahui bahwa kemampuan guru melaksanakan penilaian sikap sebesar 6,67\% yang masuk pada kategori sangat baik, 86,66 \% pada kategori baik, 6,67 $\%$ pada kategori kurang dan $0 \%$ pada kategori sangat kurang. Adapun untuk pelaksanaan penilaian pengetahuan 93,33\% pada kategori sangat baik, 6,67\% kategori baik, $0 \%$ pada kategori kurang dan sangat kurang. Selanjutnya, untukpelaksanaan penilaian keterampilan belum ada yang masuk pada kategori sangat baik (0\%), 26,67\% pada kategori baik, 73,33 \% pada kategori kurang dan $0 \%$ pada kategori sangat kurang (sesuai pada Tabel 2). Berdasarkan data ini dapat dilihat bahwa dari ketiga aspek untuk pelaksanaan penilaian, kemampuan tertinggi yang dimilki oleh guru MIN Punia Mataram yaitu pada aspek pelaksanaan penilaian pengetahuan, dimana hampir seluruhnya memiliki kemampuan sangat baik. Namun bertolak belakang dengan kemampuan melaksanakan penilaian keterampilan,dimana tidak ada guru yang memiliki kemampuan kategori sangat baik, sebagian besarnya hanya memiliki kemampuan pada kategori kurang.

Kemampuan guru pada melaksanakan penilaian keterampilan masih kurang, karena sebagian besar guru jarang melakukan penilaian menggunakan praktik dan sangat jarang sekali bahkan ada beberapa guru tidak pernah melakukan penilaian menggunakan penugasan proyek. Sementara kemampuan melaksanakan penilaian sikap, secara umum memiliki kemampuan pada kategori baik, hanya sebagian kecil yang memiliki kemampuan pada kategori sangat baik. ini memperlihatkan bahwa kemampuan guru dalam pelaksanaan penilaian sikap masih perlu untuk ditingkatkan.

Tabel. 3 Data kemampuan Guru Melaksanakan penilaian dari Sudut Pandang Siswa

\begin{tabular}{|l|l|}
\hline Tingkat Kemampuan Guru & Persentase \\
\hline Sangat Baik & $41,54 \%$ \\
\hline Baik & $56,92 \%$ \\
\hline Kurang & $1,54 \%$ \\
\hline Sangat kurang & $0,00 \%$ \\
\hline
\end{tabular}

Sementara kemampuan guru dalam melakukan penilaian dilihat dari sudut pandang siswa, diperoleh bahwa guru yang memiliki kemampuan penilaian dengan kategori sangat baik sebanyak 41,45\%, kemampuan katagori baik sebesar 56,9\% dan kategori kurang sebesar 1,54\% (sesuai pada Tabel 3). Jadi dari hasil angket yang diisi oleh 65 siswa MIN Punia Mataram memperlihatkan bahwa rata-rata kemampuan guru dalam melakukan kegiatan penilaian baik pada aspek sikap, pengetahuan dan keterampilan berada pada kategori baik.Dengan demikian, baik berdasarkan angket guru maupun angket siswa, kemampuan guru MIN Punia Mataram dalam melaksanakan penilaian adalah sama, yaitu tergolong baik. 
Adapun kemampuan guru dalam mengolah hasil penilaian tergolong sangat baik. Hasil analisis keseluruhan aspek, rata-rata kemampuan guru dalam mengolahhasil penilaian sebesar 53,55\% guru memiliki kemampuan pada kategori sangat baik, sebesar $40 \%$ pada kategori baik, 3,33\% pada kategori kurang dan sangat kurang (sesuai pada Tabel 4). Ini memperlihatkan bahwa dari 15 guru hanya setengahnya yang memiliki kemampuan pada kategori sangat baik, serta masih ada yang memiliki kemampuan kurang. Rata-rata guru yang memiliki kemampuan pada kategori kurang ini lemah dalam mengolah hasil penilaian khususnya pada aspek sikap. Guru MIN Punia Mataram masih bingung cara mengolah hasil penilaian sikap siswa yang sudah diperoleh.

Tabel. 4 Kemampuan Guru Mengolah Hasil Penilaian

\begin{tabular}{|c|c|c|c|}
\hline \multirow{2}{*}{$\begin{array}{c}\text { Tingkat } \\
\text { Kemampuan Guru }\end{array}$} & \multicolumn{3}{|c|}{ Mengolah Hasil Penilaian } \\
\cline { 2 - 4 } & Sikap & $\begin{array}{c}\text { Pengetahuan \& } \\
\text { Keterampilan }\end{array}$ & Rata-rata \\
\hline Sangat Baik & $20,00 \%$ & $86,66 \%$ & $53,33 \%$ \\
\hline Baik & $73,33 \%$ & $6,67 \%$ & $40,00 \%$ \\
\hline Kurang & $0,00 \%$ & $6,67 \%$ & $3,34 \%$ \\
\hline Sangat Kurang & $6,67 \%$ & $0,00 \%$ & $3,34 \%$ \\
\hline
\end{tabular}

Selanjutnya kemampuan guru dalam mengolah hasil penilaian jika dilihat dari tiap aspek, yaitu aspek sikap dan aspek pengetahuan serta keterampilan. Kemampuan guru dalam melakukan pengolahan penilaian sikap diperoleh persentase tertinggi pada kategori baik yaitu sebesar 73,33\%, hanya $20 \%$ yang masuk pada kategori sangat baik dan masih ada 6,67\% yang berada pada katagori sangat kurang. Sementara kemampuan guru dalam mengolah hasil penilaian pengetahuan dan keterampulan ditemukan ada 86,66 $\%$ guru yang sudah memiliki kemampuan dengan kategori sangat baik, dan 6,67 \% pada kategori kemampuan baik dan kurang serta tidak ada yang masuk pada kategori sangat kurang (sesuai pada Tabel 4). Hal ini memperlihatkan bahwa kemampuan guru dalam mengolah hasil penilaian sikap masih kurang dibandingkan dengan kemampuan dalam mengolah hasil penilaian pengetahuan dan keterampilan.

Rendahnya kemampuan guru MIN Punia Mataram dalam mengolah hasil penilaian khususnya ranah sikap, karena selama ini guru MIN Punia masih jarang membuat rekapitulasi sikap peserta didik dalam jangka waktu satu semester dan membuat rumusan deskripsi sikap menggunakan kalimat yang memotivasi dengan menyebutkan perkembangan sikap yang sangat baik dan atau baik.Jikalaupun beberapa guru pernah membuat hal tersebut namun seringkali belum terdokumentasikan secara baik dan lengkap

Adapun kemampuan guru dalam memanfaatan dan menindaklanjuti hasil penilaian dapat digolongkan baik. Hasil analisis seluruh aspek menunjukkan bahwa diperoleh hanya 13,33\% yang masuk pada kategori sangat baik, $40 \%$ kategori baik, $26,67 \%$ pada kategori kurang dan 20\% pada kategori sangat kurang (sesuai pada tabel 5). 
Hal ini memperlihatkan bahwa kemampuan guru dalam memanfaatkan dan menindaklanjuti hasil penilaian masih perlu ditingkatkan.

Tabel. 5 Kemampuan Guru Memanfaatan dan Menindaklanjuti Hasil Penilaian

\begin{tabular}{|c|c|}
\hline Tingkat Kemampuan Guru & Persentase \\
\hline Sangat Baik & 13,33 \\
\hline Baik & 40,00 \\
\hline Kurang & 26,67 \\
\hline Sangat Kurang & 20,00 \\
\hline
\end{tabular}

Selama ini bentuk tindak lanjut yang dilakukan guru MIN Punia Mataram yaitu melakukan program remedial bagi peserta didik yang belum mencapai kriteria ketuntasan minimal (KKM) per KD muatan pelajaran.Teknik yang sering dilakukan untuk remedial adalah dengan pemberian bimbingan secara kelompok dan pemberian bimbingan melalui tugas-tugas latihan secara khusus, namun sangat jarang melakukan bentuk tindak lanjut yag berupa pemberian bimbingan secara perseorangan, pemberian pembelajaran ulang dengan metode dan media yang berbeda dan pemberian bimbingan dengan memanfaatkan tutor sebaya secara individual maupun kelompok. Bentuk-bentuk tindak lanjut yang diberikan belum maksimal menyentuh karakter peserta didik secara personal masih hanya bersifat kolektif.

Sedangkan bentuk tindak lanjut yang sering dilakukan kepada peserta didik yang telah melampaui kriteria ketuntasan minimal (KKM) per KD muatan pelajaran yaitu memberikan tugas untuk dikerjakan peserta didik secara kelompok dan memberikan tugas kepada peserta didik secara mandiri.

\section{SIMPULAN}

Berdasarkan hasil penyajian dan analisis data serta pembahasan dapat dibuat kesimpulan bahwa kemampuan guru MIN Punia Mataram dalam melaksanakan penilaian hasil belajar berdasarkan kurikulum 2013 sudah baik. Pada aspek kemampuan merencanakan penilaian guru MIN Punia Mataram tergolong sangat baik (90\%). Pada aspek kemampuan melaksanakan penilaian guru MIN Punia Mataram tergolong baik (73,33\%). Pada aspek kemampuan mengolah hasil penilaian juga tergolong sangat baik $(93,33 \%)$. Serta pada aspek kemampuan memanfaatkan dan menindaklanjuti hasil penilaian tergolong baik $(53,33 \%)$.

\section{DAFTAR PUSTAKA}

Direktorat Jenderal Pendidikan Dasar dan Menengah Kementerian Pendidikan dan Kebudayaan. Panduan Penilaian untuk Sekolah Dasar (SD). Jakarta: 2015.

Keputusan Menteri Agama nomor 117 tahun 2014 tentang Implementasi Kurikulum 2013 di Madrasah. 
Lampiran Peraturan Menteri Pendidikan Nasional nomor 16 Tahun 2007 tentang Standar Kualifikasi Akademik dan Kompetensi Guru.

Peraturan Pemerintah Republik Indonesia nomor 74 tahun 2008 tentang Guru.

Peraturan Menteri Pendidikan dan Kebudayaan nomor 81 A tahun 2013 tentang Implementasi Kurikulum.

Sugiyono.2010.Metode Penelitian Pendidikan;Pendekatan Kuantitatif, Kualitatif, dan $R \& B$. Bandung: Alfabeta. 